\title{
ZULU YOUTH INTERPRET AND TRANSLATE METAPHORS IN HEBREW POETRY: AN EMPIRICAL STUDY
}

June F Dickie

University of KwaZulu-Natal

\section{Abstract}

Biblical poems make extensive use of metaphors which related to the culture of the original writers. This study explores how Zulu youth in South Africa interpret some of these metaphors from their context. It also gave them the opportunity to translate some biblical metaphors for their peer-group, using images that are more meaningful to them. Their compositions show some insightful interpretation of the Hebrew texts, particularly with respect to their use of new metaphors (often in an expanded form). These new metaphors tend to be within the same domain as those in the original text.

The ambiguity inherent in metaphor offered space for the Zulu youth to introduce new (and insightful) imagery in translating metaphors from another culture. The process is worth extending to other communities to enrich our understanding of how people from different contexts perceive and think.

Key words: Biblical Poetry; Metaphors; Community; Cultural Interpretation; Zulu

\section{Introduction}

Conceptual Metaphor Theory (Lakoff and Johnson 1980) suggests that metaphors are based on embodied experience and are thus universal. ${ }^{1}$ However, work in minority languages indicates that conceptual metaphors are not universal but are shaped by the sociocultural worldviews of indigenous speakers (Idstrom and Piirainen 2012). It is possible that emotions of fear, joy, etc. are universal, but the metaphors or images triggering these emotions, ${ }^{2}$ are culture specific. Indeed, the diversity of metaphors across cultures (Kövecses 2005) points to the importance of cross-cultural factors that shape experience. This article seeks to provide further data from a non-European language, supporting a cognitive-cultural theory of metaphor (Kövecses 2017) as a necessary complement of the (cognitive) experiential view.

The scientific value of exploring novel metaphors is two-fold: First, a new metaphor can provide revelatory insight into a particular concept (Perdue 1991:27). ${ }^{3}$ Thus, a comparison of different metaphors used to describe a similar (emotional) experience can be very enlightening, revealing "new perspectives" (Lundin et. al. 1999:169-171).

1 Lakoff and Johnson (2003:218) posit that the basis of metaphor is "experienced reality", which seems to leave more room for variation between cultures in terms of experience, and thus the metaphor used.

2 A metaphor not only carries the content of the experience, but also the associated emotion (Punter 2007:13; Ricoeur 1975:190).

$3 \quad$ Also see Lakoff and Johnson 2003:139, 142. 
Second, a cross-cultural study of the way metaphors are interpreted, indicates what the readers bring to the text from their own contexts.

Reception Theory (e.g. Iser 1974) posits that, because of "gaps"4 in a text (arising from translation ambiguities and the use of metaphors, Fretheim 2007:51-52), readers use their imagination, experience, and societal conventions to make sense of the text. This is in line with Relevance Theory (e.g. Gutt 1992): people try to make sense of messages according to their experience and background (Soukup 1997:107). This study thus seeks to use a study of metaphor to give insight into the Zulu way of thinking and the experience they bring to interpreting text.

A third scientific value of this study is that assessing the power of biblical metaphors, reveals to some extent the novelty of interpretation by Zulu readers.

Two conceptual frameworks are important in this study. First, the notion of literary functional equivalence (as advocated by Wendland 2004) is followed for the translation of poetry. This maintains that the function of the poetic device in the original language must be determined, and then the same function achieved in the receptor language, using an indigenous poetic device (which may be the same as that used in the source text, but not necessarily so). Functions achieved by poetic devices include setting boundaries (e.g. through inclusion or parallelism), holding text together (e.g. by the repetition of key terms or the use of chiasm), aesthetic beauty (e.g. through metaphorical language), and adding rhetorical force (e.g. by repetition, chiasm, and metaphor). It is important that the translation should sound like a poem. As Bisschops (2003:113) notes, "Literary metaphors have a nature of their own and must therefore be interpreted correspondingly." The poetic devices must be "translated" into indigenous poetic devices that achieve the same aesthetic and rhetorical functions.

Second, the "domestication approach" is followed for the translation of poetic images. ${ }^{5}$ Maalej (2008:63) argues that the translatability of a source language metaphor does not depend on its "boldness" or "originality" but on "the extent to which the cultural experience and lexical matrices on which it draws are shared by speakers of the particular target [or receptor] language". When the cultural experiences of the source and receptor communities are very different, the domestication approach chooses to replace foreign cultural images in the source text with more meaningful images from the receptor culture (Izgarjan and Prodanovic-Stankic 2015:26). This is necessary when an image has either no meaning (or limited meaning) for the audience, or a contrary meaning. ${ }^{6}$ As MillerNaudé and Naudé (2010:306) note, "A translation cannot travel to new surroundings without adapting to its new environment." This is in line with the thinking of many African biblical scholars. ${ }^{7}$ For example, Masoga (2004:143) asserts that the Bible must

\footnotetext{
"Gaps" implies a lack of definiteness of meaning.
}

5 Nord (2001:103) argues that a Bible translation should seek to address the cultural gap between the source and receptor cultures by either "present[ing] a strange culture in a way that allows readers from a culture distant in time and space to understand and respect its otherness" or by "show[ing] where these texts - in spite of their strangeness and ancientness - have something to say to people living in a modern culture". The former is the "foreignisation" approach, the latter the "domestication" approach.

6 For example, "horn" has a positive connotation in the Bible, but in Zulu the term may have a positive or negative nuance (the latter in the context of witchcraft).

7 Marais (2008:40) agrees, claiming that "in the South African context, translation should involve indigenisation: foreign texts ... should be translated into South African languages using indigenous forms ..." 
relate to the community reading it, "using their indigenous contexts to interpret this indigenous text". "Their indigenous contexts" includes all that the readers bring to the text, and the text must be "indigenous" in the sense of using local means of expression, including local metaphors. This enables the biblical text to then be relevant to the lives of the readers, a prime concern for the African theologian, David Adamo (2005:3).

The aim of this study is to explore the interpretation of biblical metaphors by Zulu youth and their translation of such images into their own language, using metaphors that are meaningful to them. As Lakoff and Johnson (2003:247) note, empirical data (based on real-life usage of language) is helpful for understanding the value of metaphor because "Every question about the nature of conceptual metaphor and its role in thought and language is an empirical question." Thus the examples emerging from this empirical study can add to the pool of understanding of the role of metaphor, adding data from the Zulu community.

\section{Research methods and design}

Zulu youth interested in poetry were invited to participate in "Psalms workshops" during which they made their own translations of selected psalms, using various features of Zulu oral art. The participants came from three church groups (one in Durban and two in Pietermaritzburg) and a Pietermaritzburg poets' group. The first group consisted of a youth group from a church in one of the townships near Durban, linked relationally to the researcher's home church. The second group came from various Anglican churches in Pietermaritzburg and comprised ten young people (of both genders) and three older women (members of the Cathedral choir). The third group were ten students (of both genders) from the Lutheran Theological Institute, and the fourth group consisted of 1015 members (mainly male youth) from the Tree of Life poetry group. This latter group meets weekly in the Central Library to perform their own poetry. Most of the participants are from the Zulu community, but some speakers of other African languages also participated, all working in their own mother tongues. The participants were volunteers who agreed to take part in a workshop held over three days for about six hours per day. Separate workshops were held for the four different groups.

At each workshop, participants learned the basics of Bible-translation principles, poetics (Hebrew and Zulu praise-poetry), and rhythm (as evidenced in Zulu music and poetry). Three biblical psalms were then studied, one per day. The first psalm was a short psalm of praise, Ps. 134. Participants studied the poetic devices, the functions achieved thereby, and the meaning of key words used in the text. They then translated Ps. 134 into their own languages, using indigenous poetic devices and metaphors. Once the translations had been assessed for basic accuracy, the participants converted them into performances (using rap, spoken poetry or song) which were presented to the whole group. The process was repeated on the second and third day, using Ps. 93 and a portion of Ps. 145. After the third day of the workshop, the group presented a final performance to the local church, or a group of friends and family.

Data consisted of the poems composed by the participants and video recordings of their performances. They also completed questionnaires at the end of the process, and interviews were conducted with a sample (four participants and three audience members) from each group. 
The poems composed by the youth were analysed in terms of their poetic features and the functions they achieved, relative to the functions performed by the Hebrew poetic features of the relevant psalm. Particular attention was given to cases where participants understood the biblical metaphors in an unusual way, imposing their own contexts on the text (as per Reception Theory). The use of novel metaphors in their translations of the psalms was also studied with interest.

Ethical approval was obtained from the University of KwaZulu-Natal to conduct this study. The Protocol Reference Number is HSS/1602/015D.

\section{Results}

This article focusses on some translations of Ps. 134 and Ps. 93. Ps. 134 only has three verses, but includes a number of poetic features. Ps. 93 has both dramatic imagery and powerful rhetorical structure, using threefold-parallelism. The first example selected (based on Ps. 134) illustrates two of the poets' unusual interpretations of the biblical text. To facilitate understanding, a literal translation (viz. English Standard Version) of Ps. 134 is first given:

\section{Psalm $134($ ESV)}

1. Come, bless the LORD, all you servants of the LORD, who stand by night in the house of the LORD!

2. Lift up your hands to the holy place and bless the LORD!

3. May the LORD bless you from Zion,

He who made heaven and earth.

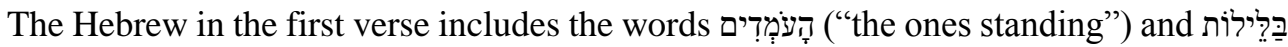
("at night"). Most scholars (e.g. Hossfeld and Zenger 2011:488) interpret "the ones standing" to mean "being in the service of" (as in other biblical texts such as 1 Kgs. 1:2 and Deut. 10:8). Similarly, "at night" is usually understood literally, with reference to the priests doing night guard-duty (Kittel 1929:281-282), or an evening ritual (De Claisse et. al. 2014:940), or as the continuation of priestly service into the night (Hossfeld and Zenger 2011:488). "Night" could also be metonymic of "day and night" (meaning all the time), as in 1 Chron. 9:33. However, biblical lexicons (such as Brown, Driver, and Briggs) indicate that both words can also take on metaphorical meanings, "standing" understood as "enduring" and "night" understood as "a time of trial". Although no known printed scriptures choose the metaphorical interpretation of this verse, ${ }^{8}$ two of the Zulu youth (both going through significant troubles) independently understood the text as referring to "those enduring through trial" or "you who hold on to the LORD in difficulties" (e.g. Dickie 2017, Item 17). The "gap of ambiguity" in the Hebrew text enabled them to interpret the words metaphorically, from the background of their personal contexts, rather than literally, as is generally done.

${ }^{8}$ However, see F. Olojede 2015. 
Another translation of Ps. 134 introduces additional components in v. 3:

Example 1 (Dickie 2017, Item 23)

3a. May the Lord of lords bless you from Zion

3b. May he bless you,

$3 \mathrm{c}$. this one who separates darkness and light

$3 \mathrm{~d}$. who separates water and sea.

The first notable characteristic is the repetition of the idea in $3 a$, in $3 b$ (although in a "stepped-down" form, i.e. reduced). This is to give focus and to support the rhythm structure. Then, in $3 \mathrm{c}$, an additional image is presented to that in the biblical text. Clearly the reference is to the creation of the earth in Gen. 1-2, as is the biblical image (creating "heaven and earth"), but the focus is on "separating", and this idea is repeated in $3 \mathrm{~d}$ with a parallel construction (again for focus and rhythm purposes). The introduction of images of separation in $3 \mathrm{c}$ and $3 \mathrm{~d}$ could highlight a theme throughout the three verses, viz. the people of God are a separated people (emphasised by "servants of the LORD" and being "in the house of the LORD" in v. 1), and serve a God who is separate, or set apart, from all others (the meaning of "holy"9 in v. 2). Thus through the Zulu poet's introduction of a slightly different metaphor in v. 3 , he has succeeded in emphasising an important truth in the psalm.

The next psalm studied in the workshops (Ps. 93) includes strong imagery of "overwhelming waves" in the central verses, viz. 3 and 4. A literal English translation of these verses follows, and then some Zulu examples are discussed.

\section{Psalm 93:3-4 (ESV)}

3. The floods have lifted up, O LORD, the floods have lifted up their voice, the floods lift up their roaring.

4. Mightier than the thunders of many waters, mightier than the waves of the sea, the LORD on high is mighty.

The imagery of rising water needs to be understood first in its original context. The background is Ugaritic and Canaanite mythology, where Baal fights and defeats the chaos-enemy, (the god) Sea (Hossfeld and Zenger 2011:449). For ancient Israel, the sea symbolised the unknown, the feared. By metonymy, it may also refer to the hostile nations who opposed Israel and thus God (Bullock 2001). It links back also to the threatening waters in Gen. 1:2, before order was established with the separating of land from the sea. Thus the metaphor refers to that which threatens and provokes fear. However, as the Zulu community lives inland and does not experience overwhelming waves, the imagery is not particularly meaningful to them. Thus they were encouraged to find other symbols of things which provoke fear in them. The most popular metaphor

\footnotetext{
${ }^{9}$ The Hebrew word usually translated as "holy" has the notion of being set apart for a special purpose.
} 
was that of "strong wind". Perhaps this was an attempt to maintain an image from nature that was part of the poets' common experience. An example using this imagery follows:

Example 2 (Dickie 2017, Item 28)

Umoya uyavunguza $(k e)$

Izivungu-vungu ziyavunguza, Mdali

Kuvunguza sansunami.
The wind is blowing (filler)

Gales are blowing, Creator,

Blowing a tsunami.

Others combined several metaphors (but all from the domain of natural phenomena), as in the example below:

\section{Example 3 (Dickie 2017, Item 7)}

Noma umfula ungagcwala uphuphume, Even if the river is full, overflowing noma umlilo ungavutha ubuhangu-hangu, even if the fire burns with scorching heat noma ulwandle lungenza unonakalo, even if the sea is causing destruction

Of interest in this translation is the use of the ideophones gcwala ("to be full to capacity": Nyembezi 1990:46) and hangu (implying scorching heat: Dent and Nyembezi 1969). Ideophones provide a very descriptive intensification of a characteristic, often replacing a metaphor in another language (Hermanson 2004:56-58).

Other poets interpreted the "floods" as difficulties or enemy attacks, thus removing the metaphorical image. However, the poet below added a simile to bring in an image (that of a lion), again from the domain of nature:

Example 4 (Dickie 2017, Item 6)

Noma isitha singahlasela, Jehova

Even if the enemy attacks, LORD, sihlasele nhlangothi zombili sihlasela kuhle kwebhubesi it attacks both ways, it attacks well like a lion,

The composition below interprets the original "waves" metaphor as 'enemy', including a new metaphor (wind), and a simile (like a lion), all within the same poem.

Example 5 (Dickie 2017, Item 12)

Nakuba isitha sibhodla okwebhubesi, Nakuba izivunga-vunga zisihlasela ngamandla, Nakuba umoya uvunguza ngamandla,
Even tho' enemy roars like a lion, Even tho' strong winds attack with strength,

Even tho' wind blows strongly with power,

Ps. 93:4 continues the refrain begun in v. 3, and in the Hebrew the same metaphor of rising water is used. In order to give the same message, viz. that the LORD is mightier than the threat in v. 3, there should be a link between the imagery of these two verses. Most of the Zulu poets did provide such a link. The poet in the example below maintains the imagery of powerful water in both vv. 3 and 4 : 
Example 6 (Dickie 2017, Item 18)

Imifula ihlokoma kuSomandla, Imifula ihlokoma ngezwi elikhulu kuSomandla,

Imifula ihlokoma ngezwi elikhulu kuSomandla,

Ngaphezu kwemidumo yamagagasi amanzi

ungaphezulu kwemidumo yolwandle uphakeme ngamandla, uSomandla.
Rivers roar to the Almighty

Rivers roar with a big voice to the Almighty,

Rivers roar with a big voice to the Almighty

Above the thunder of the waves of waters

You are above the thunder of the sea You are exalted with power, Almighty!

The next example introduces two metaphors in v. 3: an enemy roaring like a lion, and strong wind. V. 4 refers back to both of these metaphors, thus communicating the same message as in the source text.

\section{Example 7 (Dickie 2017, Item 12)}

3a. Nakuba isitha sibhodla okwebhubesi,

3b. Nakuba izivunga-vunga zisihlasela, ngamandla

3c. Nakuba umoya uvunguza ngamandla,

4a. Inamandla Nkosi ngaphezu kwebhubesi

4b.inamandla Nkosi ngaphezu

kwezivungu-vungu

4c. inamandla Nkosi ngaphezu

kwezivungu-vungu

ezivunguza ngamandla
Even tho' enemy roars like a lion,

Even tho' strong winds attack with strength,

Even tho' wind blows strongly with power,

Powerful Lord, above the lion

powerful Lord, above the blowing (storms)

powerful Lord, above the blowing (storms) that blow with power

The poet below similarly linked the metaphor in v. 3 with that in v. 4, but also added a new metaphor in v. 4 (that of mountains, again from the domain of natural phenomena). This new image is an attempt by the poet to intensify the message, wanting to emphasise that the LORD is higher than even the highest thing known to humanity:

Example 8 (Dickie 2017, Item 19)

3a. Imifula ingcwale kakhulu, Nkosi

3b. Ulwandle nemifula kuzwakala ngomsindo

3c. Ngomsindo omkhulu ulwandle luyezwakala.

4a. Unamandla ukwedlula umsindo ulwandle

4b. Unamandla ukwedlula umdumo wamagagasi asolwandle

4c. Unamandla unamanela ukwedlula izintaba euphakemeyo, Somandla!
Rivers they are very full, king/lord Oceans and rivers they are heard by sound

Big sound from the ocean is heard

You are mighty in spite of sound of ocean

You are mighty in spite of riot of waves of ocean

You mighty enough in spite of mountains that are high, Almighty! 
An interesting use of imagery and word-choice is shown in the following translation by a Zulu youth of a few cola from Ps. 93. The ESV translation appears in brackets below each colon):

Example 9 (Dickie 2017, Item 6)

1c. Jehova, uyingonyama

3a. Noma isitha singahlasela, Jehova

3b. sihlasele nhlangothi zombili,

3c. sihlasela kuhle kwebhubesi,

4a. kepha unamandla kunesitha,
LORD, you are the royal lion

(he has put on strength as his belt)

Even if the enemy may attack, LORD

(The waves have lifted up, o LORD), attacking both ways,

(The waves have lifted up their voice), attacking fiercely like a lion,

(The waves have lifted up their voice on high).

but you are more powerful than enemy

(Mightier than the thunder of the waves)

The imagery in cola $1 \mathrm{c}$ and $3 \mathrm{c}$ is similar, although a metaphor is used in 1c ("the royal lion") and a simile in $3 \mathrm{c}$ ("like a lion"). First, the use of a metaphor followed by a simile suggests that the enemy may try to appear strong, but the real lion (or strong one) is the LORD. This seems to be a powerful insight. Further, the introduction of the "lion" metaphor in $1 \mathrm{c}$ is very creative, using the attribute of power (symbolised by the lion) to translate the Hebrew idea of "having put on strength as a belt". Second, although both $1 \mathrm{c}$ and $3 \mathrm{c}$ use the image of a lion, the words used are significantly different. The first, attributed to the LORD as a metaphor translating his strength (cf. "you are robed in power" in the ESV), is the word for the royal lion, the symbol associated with the royal house of the Zulu people. In contrast, the word used to indicate the way the enemy is attacking, is that of a common lion. Thus the poet has cleverly contrasted the real strength of the LORD and the lesser strength of the enemy.

Another example where the Zulu poet's translation of a metaphor offers insight is shown below:

Example 10 (Dickie 2017, Item 24)

3a. uSimakade wase Siyoni

3b. makahlise izibusiso phezu kwenu

3c. Engathi ningathela izibusiso

3d. kulowo owadala izulu nomhlaba.
The LORD from Zion

may he bring down blessings upon you.

May you bear blessings

from the Creator of heaven and earth.

The single word "bless" in the Hebrew in v. 3 was transformed by the poet into two images, first, that of God bringing down blessings upon the person, and then of the person being able to "bear" the blessings that are "brought down". There are some rich insights in this translation: first, the notion of something tangible (that can be "brought down", supposedly from above) involved in the act of blessing, and then second, that the recipient of blessings has a responsibility to bear this good thing they are given. Thus, although the Hebrew text did not use a metaphor here, the introduction of this picture language is powerful and easily visualised, and there is new insight as to the responsibility of the recipient. 
A final example comes from the third psalm translated by the empirical poets, viz. Ps. 145. This example reveals a cultural norm within the Zulu community, that of grandparents "raising the young". V. 4a in English (ESV) reads, "One generation shall commend your works to another", which is a rather dull image compared to the Zulu version below:

Example 11 (Dickie 2017, Item 36)

4a. Abazali badumisa imsebenzi yakho eziqaneni,

4b. nasesi zukulwanene sabo.
Parents praise your work to their children,

even to their grandchildren.

The Hebrew expression "one generation to another" has been filled out with two parallel images, and as fits the Zulu culture, it includes not just parents communicating with children, but also with grandchildren.

From the interviews, a few responses indicate how the participants and audience experienced the process. Comments include: “... [the Nguni people will enjoy having more songs like these because they are] done in a way that people can relate to and understand better" (Interview 4); "the translation ... is much easier to understand than the original translation we have" (Interview 5); and "[being part of the workshop] I discovered the potential of transforming the scripture ... by understanding the context of the psalms. I have learned to be part of the process of transforming the scripture for my context" (Interview 6).

\section{Importance of local context in the choice and interpretation of metaphors}

The Zulu poets brought their own experience to their understanding of the biblical metaphors. With the first psalm there was no prior discussion of the meaning of the text, and the ambiguity allowed readers to bring their own context into the interpretation. When working with the second psalm, discussion of the historical background preceded the poets' compositions. Thus, they understood the imagery of "floods" better, and were able to find appropriate images that conveyed the same meaning. At times they replaced the Hebrew metaphor with an ideophone, or with an extended metaphor (often using two parallel lines, repeating the image or complementing it).

Metaphorical language is full of ambiguity, and this study illustrates the claim of Reception Theory, that gaps in the text leave room for individual interpretation, particularly if closure is not imposed on the meaning of the text. As Lakoff and Johnson (2003:218) note, metaphor emerges from "experienced reality" and the difficult experiences of two of the poets coloured their understanding of the language used in Ps. 134:1. Thus, the empirical examples underscore the impact of the readers' experiences in their interpretation.

When a metaphor is understood in its historical context, the force of the image is probably understood as by the original audience. However, to communicate this emotion and experience effectively for their own community, the Zulu poets generally changed the picture language, often using different metaphors to underline the emotion they were trying to convey. The empirical compositions highlight the potential insights and strength of translations when the poets are free to adapt the metaphors. 
Apart from the value of translating metaphors appropriately for one's own culture, others (outside that culture) can also benefit. The introduction of the "separating" metaphor in Example 1 adds a new focus to the concept of holiness in Ps. 134. Similarly the use of the "lion" metaphor in Example 9 brings a rich, new understanding to Ps. 93. Theorists (e.g. Lakoff and Johnson 2003:139, 142) argue that imaginative metaphors can "[give] us a new understanding of our experience or 'provide' a new insight into a particular concept", and this study supports this assertion.

The participants in this study were not selected on the basis of skill in poetry, but were volunteers who called themselves "poetry fans". The training time in the workshops was also very limited. Despite these factors, the results show what can be achieved when "ordinary" 10 people are given the opportunity to be creative and think about picturelanguage to transmit their experiences. More imaginative results could probably have been obtained if circumstances had allowed some of the more gifted poets to participate more fully. (Several of the youth could only attend one or two of the workshops owing to family responsibilities.)

Implications emerging from the results include the need to find meaningful metaphors when translating texts for a cross-cultural, contemporary audience. The local community, in particular youth interested in poetry, has much to contribute, particularly in the translation of biblical poetry. Their interpretations of established metaphors in the Bible, as well as their innovative translations, add to the richness of biblical interpretation. Outside of the field of biblical text, one can also imagine local communities providing stimulating translations of other classical literature.

\section{Conclusion}

The responses of both participants and audience members showed that they considered the new translations within the Zulu cultural idiom to be more understandable and relevant than published translations. The audiences also assessed the new compositions as acceptable "translations", transmitting the same message (but in a more engaging way) than the old translations. Also, the young people enjoyed being part of the process of "meaning-making", an important aspect for millennials. ${ }^{11}$

With regard to the metaphors used, it seems that the Zulu poets restricted their images to natural phenomena (as did the biblical texts), although, when they chose to give a literal interpretation of the Hebrew metaphor, they referred to people ("enemies"). Other work $^{12}$ has shown that Zulu youth may invent novel metaphors (outside of the domain of natural phenomena), but that was not the case when translating original biblical texts which use metaphors of natural phenomena. It was noted, too, that sound metaphors (or ideophones) may be used in Zulu rather than visual ones, possibly as a result of it being a predominantly oral culture. However, as the Hebrew culture was also predominantly oral, it also used sound metaphors (as is evident in Ps. 93, with a focus on the sound of the rising waters). Thus there is often a good match between Zulu metaphors and those used in the Bible.

10 "Ordinary African interpreters" have much to contribute through sharing their local and indigenous interpretive resources with biblical scholarship. See West 2002.

11 The upcoming generation expects to be able to participate and share (Shirky, 2010:212-3).

12 For example, see Dickie 2018:15. A woman laments that "They make me like a car that won't start". 
The value of such a study is that the Zulu youths' translations open a window into their culture and thinking. As Naudé (2004:57) notes: “One way of 'opening up' a foreign culture is by way of interlingual translation ... in that the act of translating literary texts ... involves transferring aspects of the culture belonging to one group to that of another." Thus it serves to enrich our understanding of Zulu culture and thought processes as well as adding insight to the ancient biblical text.

\section{BIBLIOGRAPHY}

Adamo, D.T. 2001. Reading and interpreting the Bible in African indigenous churches. Eugene, Oregon: WIPF and Stock Publishers.

Bisschops, Ralph. 2003. Are religious metaphors rooted in experience? On Ezekiel's wedding metaphors. In Kurt Feyaerts (ed.), The Bible through metaphor and translation. A cognitive semantic perspective. Bern, Switzerland: Peter Lang Pub Inc, 113-151.

Brown, Driver, and Briggs, 2000. The enhanced Brown-Driver-Briggs Hebrew and English lexicon, part of Translator's Workplace within the suite of Logos software.

Bullock, C. Hassel. 2001. Encountering the Book of Psalms. Grand Rapids, MI: Baker Books.

De Claisse-Walford, N., Jacobson, R.A. and Tanner, B. (eds). 2014. Overview of the shape and shaping of the Book of Psalms: the current state of scholarship. Atlanta: SBL Press.

Dent, G.R. and Nyembezi, C.L.S. 1969. Scholar's Zulu dictionary (rev.). PMB: Shuter and Shooter.

Dickie, June F. 2017. Zulu son, oral art, performing the Psalms to stir the heart. Unpublished $\mathrm{PhD}$ thesis, University of KwaZulu-Natal, South Africa.

Dickie, June F. 2018. African youth engage with Psalms of Lament to find their own voice of lament, Journal of Theology for Southern Africa, 160:4-20.

Fretheim, T. 2007. The authority of the Bible and the imaging of God. In W.P. Brown (ed.), Engaging Biblical authority. London: Westminster John Knox Press, 45-52.

Gutt, E-A. 1992. Relevance Theory: A guide to successful communication in translation. Dallas/New York: SIL and UBS.

Hermanson, Eric A. 2004. Missionary translations of the Bible into the Zulu language. In G.L.O.R. Yorke \& P.M. Renju (eds), Bible translation and African languages. Nairobi: Acton, 41-58.

Hossfeld, F-L. and Zenger, E. 2011. Psalms (vol. 3). Minneapolis: Fortress Press. Idstrom, Anna and Piirainen, Elisabeth. 2012. Endangered metaphors. Amsterdam: John Benjamins.

Iser, W. 1974. The implied reader: Patterns of communication in prose fiction from Bunyan to Beckett. Baltimore: John Hopkins University Press.

Izgarjan, Aleksandra and Prodanovic-Stankic, Diana. 2015. Approaches to metaphor: Cognitive, translation and literature studies perspective. Monograph on Academia.edu. Novi-Sad, Serbia: University of Novi-Sad. 
Kittel, R. 1929. Die Psalmen, Kommentar zum Alten Testament 13 (4th ed.). Leipzig: D.W. Scholl.

Kövecses, Zoltán. 2005. Metaphor in culture. Universality and variation. Cambridge and New York: Cambridge University Press.

Kövecses, Zoltán. The interplay between metaphor and culture. Online: https://www.researchgate.net/publication/321314977_The_interplay_between_ metaphor_and_culture (Accessed: 4 October 2018).

Lakoff, George and Johnson, Mark. 2003. Metaphors we live by. London: University of Chicago Press. Online: https://www.cc.gatech.edu/classes/AY2013/cs7601_spring/ .../Lakoff_Johnson.pdf (Accessed: 27 November 2018).

Lundin, R., Thiselton, A.C., and Walhout, C. 1999. The Promise of Hermeneutics. Grand Rapids: Eerdmans.

Maalej, Z. 2008. Translating metaphor between unrelated cultures: A cognitivepragmatic perspective, Sayyab Translation Journal 1:60-82.

Marais, Jacobus. 2008. The language practitioner as agent: The implications of recent trends in research for language practice in Africa, JNGS 6/3:35-47.

Masoga, M. 2004. How indigenous is the Bible? Challenges facing the 21st century South African biblical scholarship, Journal for Semitics 13(2):139-158.

Miller-Naudé, Cynthia L. and Naudé, Jacobus A. 2010. The translator as an agent of change and transformation: The case of translating Biblical proverbs, OTE 23/2:306-321.

Naudé, Jacobus A. 2004. An overview of recent developments in translation studies with special reference to the implications for Bible translation, Acta Theologica. Online: file:///C:/Users/User/Desktop/Naude\%20An_overview_of_recent _developments_in_tr.pdf(Accessed: 27 November 2018).

Nord, Christiane. 2001. Bridging the cultural gap: Bible translation as a case in point, Acta Theologica 22:98-116.

Nyembezi, C.L.S. 1990. Learn more Zulu. PMB: Shuter and Shooter.

Olojede, Funlola. 2015. “...What of the Night?” Theology of night in the Book of Job and the Psalter, OTE, 28/3. Online: http://dx.doi.org/10.17159/2312-3621/2015/ $v 28 n 3 a 10$ (Accessed: 29 November 2018).

Perdue, Leo G. 1991. Wisdom in revolt. Metaphorical theology in the Book of Job. Sheffield: Academic Press.

Punter, David. 2007. Metaphor. London / New York: Routledge.

Ricoeur, Paul. 1975/9. The rule of metaphor. Toronto: University of Toronto Press.

Shirky, C. 2010. Cognitive surplus. Creativity and generosity in a connected age. New York: Penguin Press.

Soukup, P.A. 1997. Understanding audience understanding. In Paul A. Soukup and R. Hodgson (eds), From one medium to another: communicating the Bible through multimedia. Kansas City: Sheed \& Ward, 91-107.

Wendland, Ernst R. 2004. Translating the literature of Scripture. Dallas: SIL.

West, Gerald O. 2002. Indigenous exegesis: exploring the interface between missionary methods and the rhetorical rhythms of Africa; locating local reading resources in the academy, Neotestamentica 36:147-162. 